\title{
A Imprescindível Contribuição dos Tratados e Cortes Internacionais para os Direitos Humanos e Fundamentais
}

\author{
Clóvis Gorczevski ${ }^{1}$ \\ Felipe da Veiga Dias ${ }^{2}$
}

Resumo: O estudo apresentado tem como foco a demonstração da evolução e da importância do direito internacional, especialmente documentos como tratados, pactos e jurisdicionalmente cortes, para formação de um sistema coeso de proteção dos direitos humanos. A finalidade principal desta pesquisa é demonstrar que, diante de uma sociedade globalizada, o estabelecimento de parâmetros de proteção desses direitos são inestimáveis, haja vista que na esfera interna ainda ocorrem violações a tais direitos, sendo que os indivíduos carecem do resguardo ofertado somente na esfera internacional. Para tanto, adota-se como método de abordagem o dedutivo. O método de procedimento utilizado é o histórico. Como técnica de pesquisa utiliza-se a documentação indireta, a partir da pesquisa bibliográfica.

Palavras-chave: Direitos Humanos. Tratados. Relações Internacionais.

\begin{abstract}
The present study focuses on the development and the importance of international law, especially documents such as treaties, covenants and jurisdictional courts, to form a cohesive system of protection of human rights. The main purpose of this research is to demonstrate that before a globalized society, the establishment of parameters to protect these rights are priceless, considering that in the internal sphere violations of such rights still occur, and the individuals lack the guard offered only in the international sphere. The method of approach is the deductive one. The method of procedure is the historical one. As a research technique we use the indirect documentation from the literature.
\end{abstract}

Key words: Human Rights. Treaties. International Relations.

1 Possui Pós-doutorados em Direito pela Universidade de La Laguna (Espanha) e pela Universidade de Sevilha(Espanha). Doutor em Direito pela Universidade de Burgos (Espanha). Especialista em Ciências Políticas pela Universidade Luterana do Brasil (ULBRA). Graduado em Ciências Jurídicas e Sociais pela Pontifícia Universidade Católica do Rio Grande do Sul (PUC-RS). Professor do Programa de Mestrado e Doutorado em Direito da Universidade de Santa Cruz do Sul (UNISC). Advogado.E-mail: clovis.g@terra.com.br.

2 Doutorando e Mestre em Direito pela Universidade de Santa Cruz do Sul (UNISC). Especialista em Direitos Fundamentais e Constitucionalização do Direito pela Pontifícia Universidade Católica do Rio Grande do Sul (PUC-RS). Professor da Faculdade Metodista de Santa Maria (FAMES).Advogado.E-mail: felipevdias@gmail.com.

Recebido em: 20/03/2012.

Revisado em: 10/09/2012.

Aprovado em: 16/10/2012. 


\section{Introdução}

Antes de adentrar especificamente no tema dos tratados internacionais sobre direitos humanos, é necessário fornecer alguns esclarecimentos teóricos de direito internacional acerca desses instrumentos.

Tratado é uma denominação genérica para denominar um ato jurídico pelo qual duas ou mais pessoas internacionais expressam sua vontade, objetivando um fim lícito e possível. Como ensina Rezek (2005, p. 14), a expressão "tratado" refere-se a "[...] todo acordo formal concluído entre pessoas jurídicas de direito internacional público e destinado a produzir efeitos jurídicos". Contudo, os atos jurídicos praticados entre pessoas internacionais possuem uma vasta nomenclatura específica, em razão das pessoas que dele participam, da sua natureza, seu conteúdo, objeto ou fim. No sentido stricto, o termo tratado é empregado para os ajustes extremamente formais, dos quais participam os próprios chefes de Estado (ex. Tratado de Paz). Entre as denominações mais comuns, destacam-se estas: Convenção - geralmente empregada nos ajustes que estabelecem normas gerais; Protocolo - designa ajustes menos formais ou suplemento de ajustes já existentes; Pacto - designa ajustes solenes e de importância; Acordo - refere-se a ajustes de natureza econômica, comercial ou financeira; Concordata - designação empregada para ajustes realizados com a Santa Sé. Qualquer que seja sua denominação, elas são regidas pelo direito internacional público e para sua eficácia exigem algumas formalidades próprias, além de atenderem às condições de validade geral dos contratos: capacidade das partes contratantes, habilitação dos signatários, consentimento mútuo e objeto lícito e possível (ANDRADE, 1990; ACCIOLY; SILVA, 1996). Para torná-los válidos e exequíveis, é preciso ratificá-los. A ratificação não é matéria do direito internacional, mas da ordem constitucional de cada Estado que estabelece competência a um de seus órgãos para a assunção, em nome do Estado do compromisso assumido ${ }^{3}$.

3 No Brasil, os tratados são celebrados pelo Presidente da República (art. 84, VIII da $\mathrm{CF} / 88$ ) e ratificados pelo Congresso Nacional (art. 49, I da CF/88). 


\section{A Importância dos Tratados Internacionais sobre Direitos Hu- manos}

Os tratados internacionais, especificamente sobre direitos humanos, são de altíssima relevância, pois expressam a evolução da sociedade internacional ao exigirem dos Estados o reconhecimento, a promoção e a proteção desses direitos. Desde Bodin (1576) - para quem a soberania estatal era concebida como o poder supremo, absoluto, ilimitado e perpétuo sobre os cidadãos e súditos - que a questão da soberania dos Estados tem sido um dos pontos mais delicados da filosofia e das ciências políticas. No direito internacional é um dos princípios mais fortes e que, em termos práticos, impede a intervenção de qualquer poder nos atos praticados por um Estado, mesmo que eles sejam de violações aos direitos humanos. A violação do princípio da soberania dos Estados significa a violação de outros, como a ingerência em assuntos de outros Estados e a autodeterminação dos povos. Os Estados, portanto, devem apenas observar, sem qualquer intervenção, fatos que ocorrem em outros Estados. Julgando-se imunes, amparados neste princípio, muitos Estados têm sistematicamente praticado violações aos direitos humanos.

Talvez por isso a ideia de uma tutela internacional aos direitos humanos encontrou, no princípio, tanta resistência. No campo político, a resistência se deu pelos antigos e anacrônicos conceitos da soberania nacional absoluta; ideias que ainda hoje são comuns de se encontrar. E bem lembra Belli (1998, p. 152) que o conceito de soberania nacional, revestido com as mais diversas roupagens, continua a imperar em muitos Estados, seja por puro conservadorismo, seja por razões inconfessáveis. Mas a resistência deu-se também no campo jurídico. Reconhecidos tratadistas da matéria durante muito tempo sustentaram a tese de que somente os Estados - e algumas entidades de origem ou características estatais - poderiam ser sujeitos de direito internacional público, qualidade que se negava aos indivíduos com fulcro nos requisitos que diziam que o sujeito de direito internacional era o "[...] ser titular de direitos e obrigações, de participar na criação de normas internacionais, reclamar frente a outros sujeitos de direito internacional e criar outros sujeitos de direito internacional" (SOROETA LICERAS, 2000, p. 20). A pessoa natural não 
poderia, portanto, ser reconhecida como titular de direitos ou ações que somente competiam aos Estados. (CALLO, 1977, p. 36)

Contudo, modernamente, a comunidade internacional não aceita que o problema de violação dos direitos humanos seja uma questão de competência exclusiva dos Estados. A necessidade social e moral de uma defesa realmente efetiva dos direitos humanos, unida a uma crescente abertura da doutrina política e jurídica sobre a matéria, tornou possível a realização, no século XX, deste grande avanço da humanidade: o reconhecimento e a proteção dos direitos humanos pela ordem internacional. Assim, a tutela desses direitos não é mais uma questão de competência exclusiva dos Estados, mas sim um problema de toda a sociedade internacional. Essa foi uma das grandes proezas do nosso tempo. Como disse Callo (1977, p. 36), uma notável revolução “[...] ha sido la concepción de los primeros sistemas de tutela internacional de los derechos humanos".

Para Leal (1997, p. 85) essa nova forma de encarar a proteção dos direitos humanos garante uma independência teórica e científica, separando-se, gradualmente, do direito internacional, constitucional e de outros ramos, constituindo-se, embora incipiente, como um ramo com objeto e método científico que justifica sua relativa independência. Também para Cançado Trindade (2000, p. 19), os direitos humanos firmam-se, hoje, com inegável vigor, como um ramo autônomo do direito, dotado de especificidade própria.

Este novo e vasto corpus juris vem atender a uma das grandes preocupações de nossos tempos: assegurar a proteção do ser humano nos planos nacional e internacional, em toda e qualquer circunstância. (CANÇADO TRINDADE, 2000, p. 19)

Efetivamente, essa nova visão, de proteção internacional dos direitos humanos, é algo extremamente recente na história da humanidade e tem seu início com o término da Segunda Guerra Mundial. Com a liberdade de imprensa e o desenvolvimento de modernos meios de comunicação, a comunidade internacional tomou conhecimento das barbáries e atrocidades cometidas. Atitudes que envergonhavam a própria espécie humana. Isso demonstra a necessidade de uma proteção mais efetiva aos di- 
reitos humanos; o que nos levou ao processo de internacionalização desses direitos resultando na criação de sistemas de proteção internacional, em que é possível a própria responsabilização de um Estado. $\mathrm{O}$ aspecto mais positivo dessas ações foi a reformulação do conceito clássico de soberania como um poder ilimitado que não admite restrições ou exceções.

Piovesan (1998, p. 196) é enfática ao afirmar que a internacionalização dos direitos humanos foi uma resposta às atrocidades e aos horrores cometidos durante o nazismo. Se a Segunda Guerra significou a ruptura dos direitos humanos, o pós-guerra deveria significar sua reconstrução. Alves (1994, p. 3) vê ainda a garantia internacional dos direitos humanos como medida preventiva: "A afirmação dos direitos humanos como tema internacional prioritário, fundamenta-se, pois, do ponto de vista estratégico, pela percepção de que violações maciças podem levar à guerra". E, destacam-se ainda, sob esse mesmo prisma, as preocupações preventivas e autodefensivas dos Estados afluentes atemorizados com a possibilidade de serem invadidos por levas de refugiados.

\section{A Declaração Universal dos Direitos do Homem}

O marco histórico no processo de internacionalização dos direitos humanos se dá em 10 de dezembro de 1948, quando a Assembleia Geral das Nações Unidas aprova, sem nenhum voto contrário, a Declaração Universal dos Direitos do Homem; cabendo também aludir que, segundo a doutrina, esse documento serve de base para o reconhecimento como sujeito de direitos na órbita internacional. (CANÇADO TRINDADE, 2002, p. 6)

Essa Declaração, diz Piovesan (1998, p. 196), introduz uma concepção moderna de direitos humanos caracterizada pela universalidade e pela indivisibilidade desses direitos. Universalidade, porque clama pela extensão universal dos direitos humanos, sob a crença de que a condi-

\footnotetext{
4 [...] O texto foi aprovado por 48 votos favoráveis - incluindo o Brasil - e oito abstenções (Arábia Saudita, Bielorússia, Polônia, Checoslováquia, União Sul-Africana, União Soviética, Ucrânia e Iugoslávia) havendo duas ausências (Honduras e Iêmen). Vêse, portanto, que não houve nenhum voto contrário.
} 
ção de pessoa é requisito único para a dignidade e titularidade de direitos (CANÇADO TRINDADE, 2002, p. 17). Indivisibilidade, porque a garantia dos direitos civis e políticos é condição para a observância dos direitos sociais, econômicos e culturais e vice-versa. Dessa forma, o conceito de direitos humanos se vê ampliado à medida que passa a incluir não apenas direitos previstos no plano nacional, mas também direitos internacionalmente anunciados. Assim, a Declaração Universal dos Direitos do Homem de 1948 se transforma "[...] en el primer instrumento internacional general, de carácter universal, que enuncia derechos que se reconocen a toda persona." (CASTILHO, 2003, p. 51)

Com o objetivo da universalidade, sua redação é simples e direta. Constitui-se de um preâmbulo e de 30 artigos. Logo no artigo $1^{\circ}$ estão presentes, expressamente, os três princípios fundamentais da matéria: liberdade, igualdade e fraternidade, cuja origem remonta à Revolução Francesa. (COMPARATO, 2003, p. 225-226)

Os princípios da igualdade e da liberdade estão presentes na primeira parte da Declaração, que vai do artigo $3^{\circ}$ ao artigo 21 , onde constam os direitos civis e políticos: direito à vida, à liberdade, à segurança pessoal, à proibição da escravidão e da servidão; à proibição da tortura e do tratamento ou castigo cruel, desumano ou degradante; o direito a ser reconhecido como pessoa perante a lei; o direito à igual proteção da lei; o direito a um processo justo e público por tribunal independente e imparcial; à presunção de inocência até que a culpabilidade seja provada; à proibição de interferências arbitrárias na vida privada, na família, no lar, na correspondência; à liberdade de locomoção; o direito de asilo; o direito a uma nacionalidade; o direito a contrair matrimônio e a constituir família; o direito à propriedade; à liberdade de pensamento, de consciência, de religião, de opinião e de expressão; à liberdade de reunião, à associação pacífica; o direito de participar do governo de seu Estado de ter acesso equitativo ao serviço público de seu país.

O princípio da solidariedade está na base dos direitos econômicos, sociais e culturais, presentes no artigo 22 ao artigo 27: direito à previdência social; ao trabalho; ao repouso e ao lazer; a um padrão de vida capaz 
de assegurar saúde e bem-estar; à educação e a participar da vida cultural da comunidade.

A Declaração não se limitou a proteger os direitos e as liberdades tradicionais. Paralelo a isso, estendeu a proteção aos direitos das pessoas a novos setores como o direito de gozar asilo e o direito a uma nacionalidade $^{5}$, além de reconhecer a democracia como o único regime político compatível com o pleno respeito aos direitos humanos.

Os artigos finais referem-se ao direito que todos os homens têm a uma ordem social e internacional que faculte a plena realização desses direitos e de liberdades, bem como aos deveres que todos os homens têm para com a comunidade, uma vez que o livre e pleno desenvolvimento de sua personalidade só é possível na própria comunidade.

Não obstante alguns doutrinadores apresentem diferentes divisões da Declaração em relação aos direitos e liberdades previstas, sua divisão simples em duas categorias - civis e políticos e econômicos, sociais e culturais - é a mais comumente apresentada, utilizada inclusive pela ONU.

Publicada a Declaração, lembra Oliveira (2000, p. 220-221), que recebeu todas as críticas às quais estão sujeitas as obras humanas: que não tinha sentido revolucionário - bradaram os socialistas do leste; que direitos econômicos e sociais não são fundamentais - clamaram os liberais do oeste. Cada setor ideológico, filosófico, religioso e político manifestou seu particular descontentamento.

Para Leal (1997, p. 87), todas as críticas dirigidas à Declaração referem-se especialmente ao fato de não existir uma base teórica homogênea para seu conteúdo, o que resulta nas seguintes situações: (a) no corpo da declaração, direitos humanos e direitos do cidadão são integrados

5 Lembra Comparato que o Estado nazista aplicou, sistematicamente, a política de supressão da nacionalidade alemã a grupos minoritários, sobretudo a pessoas de origem judaica. Após a guerra, Hannah Arendt chamou a atenção para a novidade perversa desse abuso mostrando como a privação de nacionalidade fazia das vítimas pessoas excluídas de toda proteção jurídica no mundo. Ocorre que o asilado deixa um quadro de proteção nacional para encontrar outro. Mas aquele que foi despojado de sua nacionalidade e não encontrar um Estado disposto a recebê-lo, simplesmente, deixa de ser considerado pessoa humana. 
numa única categoria; (b) a Declaração não guarda vínculos mínimos com o presente, ou mesmo com o passado recente, pois deixa de apresentar referências a fenômenos que têm despertado a indignação de todo mundo e tampouco condena, de forma explícita, as violações dos direitos humanos; (c) a Declaração carece de um caráter político mais definido, o que a faz não ocupar uma posição clara na escala de valores políticos vigentes à sua época; (d) as referências aos direitos econômicos, sociais e culturais são mínimas e superficiais; (e) com exceção ao caput do artigo 29, não há nenhuma referência à contrapartida dos direitos, isto é, aos deveres do homem. Assim, a relação entre o Estado e o indivíduo não se apresenta proporcional ou simétrica.

Entretanto, a mais séria discussão deu-se sobre a natureza jurídica ou o valor jurídico da Declaração. Na verdade, a Declaração, por si só, não tem força cogente, já que, adotada por meio da Resolução da Assembleia Geral, que, nos termos do artigo 13 da Carta das Nações Unidas, possui competência para fazer recomendações ${ }^{6}$. Assim, Rezek (1995, p. 224) é taxativo:

A Declaração Universal dos Direitos do Homem não é um tratado, e por isso seus dispositivos não constituem exatamente uma obrigação jurídica para cada um dos Estados representados na Assembléia Geral quando, sem qualquer voto contrário, adotou-se o respectivo texto sob a forma de uma resolução da Assembléia.

Igual é o entendimento de Castillo (2003, p. 54) "Desde el punto de vista formal, en cuanto resolución de la Asamblea General, la Declaración no es un instrumento jurídicamente vinculante". Verdross (1961, p. 443) também lembra que a Assembleia Geral das Nações Unidas “[...] no tiene, en principio, competencia legislativa".

Igual é o pensamento de Comparato (2003, p. 223-224):

\footnotetext{
6 Nos termos do artigo 13, inciso I da Carta da ONU, a Assembleia Geral tem competência para “[...] iniciar estudos e fazer recomendações destinados a: "b) [...] favorecer o pleno gozo dos direitos humanos e das liberdades fundamentais [...]”.
} 
Tecnicamente, a Declaração Universal dos Direitos do Homem é uma recomendação que a Assembléia Geral das Nações Unidas faz aos seus membros (Carta das Nações Unidas, artigo 10). Nestas condições, costuma-se sustentar que o documento não tem força vinculante ${ }^{7}$.

Vale ainda lembrar que a Declaração não foi aprovada nem ratificada como tratado internacional pelos distintos Estados, de acordo com seus mecanismos constitucionais, pelo qual se obrigariam legalmente.

Contudo, muitos doutrinadores encaram a Declaração como uma interpretação autorizada dos artigos da Carta das Nações Unidas, relativos aos direitos humanos, e que teriam, portanto, efeitos legais de um tratado internacional. Assim é o posicionamento de Azevedo (1980, p. 46) para quem é possível reconhecer força cogente à Declaração, na medida em que ela se apresenta como a explicitação dos direitos humanos a que a própria Carta da ONU se refere:

Na medida em que se puder aceitar a cogência das próprias disposições da Carta da ONU sobre os direitos humanos, então será possível aceitar a cogência da própria Declaração Universal enquanto extensão ou desdobramento da Carta da ONU, explicitadora dos direitos humanos consagrados em seu texto.

Contudo, Alves (1994, p. 48) observa que, independente da posição seguida, o que se verifica na prática é uma invocação generalizada da Declaração Universal dos Direitos do Homem, como regra dotada de jus cogens, invocação esta que não tem sido contestada sequer pelos Estados mais acusados de violações de seus dispositivos.

Em resumo, aqueles que defendem que a Declaração possui força vinculante possuem fortes argumentos: (a) a Declaração é apenas uma explicitação dos direitos humanos previstos na Carta das Nações Unidas,

7 O próprio autor declara que se reconhece hoje, em toda parte que a vigência dos Direitos Humanos, independe de sua declaração em constituições, leis e tratados internacionais, exatamente porque se está diante de exigências que dizem respeito à dignidade humana, exercidas contra todos os poderes estabelecidos, oficiais ou não. 
ou seja, é uma extensão da Carta; (b) a incorporação de sua ideia básica nas Constituições nacionais; (c) sua constante invocação e referências da própria ONU quanto à obrigação legal do todos os Estados em observá-la, sem contestações; e (d) sua constante invocação como fonte de direito realizada por incontáveis tribunais nacionais.

Entretanto, qualquer posição que se sustente sobre esse tema, vale lembrar que a própria ONU considerou necessária a elaboração de outros instrumentos para dar-lhe um efetivo respaldo jurídico, tornando-a exigível.

Não obstante as controvérsias e as críticas, após a Declaração Universal de 1948, inúmeras outras Declarações e Convenções Internacionais foram elaboradas, atendendo ao que Bobbio (1992, p. 68) denominou de processo de "multiplicação de direitos", que envolveu não só um substancial aumento na quantidade de bens considerados merecedores de proteção, mas na ampliação da titularidade de alguns direitos típicos a sujeitos diversos do homem. Assim, “[...] a Declaração não tardou a produzir resultados positivos de ordem prática e a influir na vida dos povos" (OLIVEIRA, 2000, p. 201). Em verdade, desde a promulgação da Declaração, as Nações Unidas adotaram quase uma centena de Declarações ou Convenções sobre direitos humanos, sendo que muitas delas se referem a novos direitos. Cançado Trindade (2003, p. 64-65) ${ }^{8}$ ressalta que a multiplicação desses tratados deu-se tanto nos chamados "gerais" - como os dois Pactos das Nações Unidas e as três Convenções Regionais (Euro-

8 O autor cita como exemplo destes últimos, em cujos preâmbulos constam referências expressas à Declaração: a Convenção Relativa ao Estatuto dos Refugiados (1951), a Convenção da Organização Internacional do Trabalho sobre Discriminação Relativa a Emprego e Ocupação (1958), a Convenção da UNESCO contra Discriminação na Educação (1960), a Convenção das Nações Unidas sobre a Eliminação de Todas as Formas de Discriminação Racial (1965), a Convenção sobre a Supressão e Punição do Crime de Apartheid (1973), a Convenção sobre a Eliminação de todas as Formas de Discriminação contra a Mulher (1979), a Convenção sobre os Direitos das Crianças (1989), a Convenção das Nações Unidas Contra a Tortura e outros Tratamentos e Punições Cruéis, Desumanas e Degradantes (1984). Fazem também referências expressas à Declaração Universal as Convenções Regionais, a Convenção Europeia de Direitos Humanos (1950), a Convenção Americana sobre Direitos Humanos (1969) e a Carta Africana de Direitos Humanos e dos Povos (1981). 
peia, Americana e Africana) - como nos “especiais" - voltados a setores ou a aspectos especiais de proteção dos direitos humanos.

Ademais, muitas Constituições receberam fortemente sua influência, bem como o direito interno de inúmeros Estados. O Tribunal Internacional de Justiça, assim como os tribunais nacionais dos Estados Unidos da América, França, Holanda, Bélgica, Itália Espanha e Filipinas, a tomam como referência e fundamento de suas decisões (OLIVEIRA, 2000, p. 201). Por tudo isso, diz Castillo (2003, p. 55),

[...] puede afirmar-se que, en el tiempo transcurrido desde su adopción, la Declaración, en la práctica, ha cambiado de naturaleza jurídica y se ha convertido en un instrumento de carácter normativo, en el sentido de que hoy es difícil negar que hay un conjunto de derechos humanos fundamentales, enunciados en la Declaración Universal, que forman parte del Derecho Internacional general o consuetudinario.

Esse conjunto estaria composto pelo direito à vida, à proibição de escravidão, da tortura e de tratos cruéis, desumanos ou degradantes, de detenção arbitrária e de discriminação racial.

Para Piovesan (1998, p. 198) é a partir da moderna concepção de direitos humanos introduzida pela Declaração Universal de 1948 que começa a se desenvolver o direito internacional dos direitos humanos, mediante a adoção de inúmeros tratados internacionais voltados à proteção dos direitos fundamentais.

Mas, sem dúvida, o êxito da Declaração Universal deve-se ao fato de seus redatores terem fundamentado os direitos humanos - pela primeira vez reconhecidos em um texto universal - em um elemento básico: a dignidade da pessoa (sobre o tema desse princípio alude-se a obra de Sarlet (2008). É essa a única ideia-força que aglutina as diferentes concepções culturais filosóficas, ideológicas, religiosas, morais e sociais, presentes no mundo contemporâneo. Nesse sentido, diz Piovesan (2000, p. 143) que, desde o preâmbulo, a Declaração afirma que a dignidade é inerente a toda pessoa humana, titular de direitos iguais e inalienáveis. Em outras 
palavras: a condição de pessoa é o requisito único e exclusivo para a titularidade de direitos.

A dignidade da pessoa humana, como fundamento dos direitos humanos é concepção que, posteriormente, vem a ser incorporada por todos os tratados e declarações de direitos humanos. (PIOVESAN, 2000, p. 143)

Inegavelmente, afirma Comparato (2003, p. 225), a Declaração Universal dos Direitos do Homem representa a culminância de um processo ético - iniciado com a Declaração da Virgínia, passando pela Declaração de Independência dos Estados Unidos e pela Declaração dos Direitos do Homem e do Cidadão - o que levou ao reconhecimento da igualdade essencial de todo ser humano em sua dignidade de pessoa, isto é: a fonte de todos os valores.

E não se pode se esquecer das mudanças extraordinárias que ocorreram em várias partes do mundo nos últimos anos do século $\mathrm{XX}$ - que levaram o presidente norte-americano George Bush, no Congresso Nacional em 11 de setembro de 1990, a anunciar uma nova ordem internacional (neoliberalismo universal - apesar desse modelo encontrar-se atualmente em crise). Efetivamente, entrou-se numa nova era, a da globalização, na qual há poucas opções (ou por vezes nenhuma), ideais ou escolhas políticas. Uma era em que o pragmatismo, a competição e o desemprego não dão espaço para o pensamento, o confronto de ideias, a solidariedade. É nesse panorama, nessa nova ordem mundial que a Declaração Universal dos Direitos do Homem ganha uma nova dimensão, apresentando-se como uma proposta universal libertadora.

\section{Os Pactos}

Enquanto a Declaração Universal dos Direitos do Homem era somente uma Declaração, sem meios para torná-la exigível, a Comissão de Direitos Humanos, iniciou, ainda em 1949 a preparação de um instrumento, elaborado em forma de Convenção Internacional, para torná-la exequível. Grandes divergências ocorreram se os direitos civis, políticos, 
econômicos, sociais e culturais deveriam ser regulados juntos em uma só convenção ou separadamente. Em 1954, a Comissão apresentou dois anteprojetos de Pactos que tratavam separadamente dos direitos, um Pacto contendo os direitos civis e políticos e outro com os direitos econômicos, sociais e culturais. Ambos continham disposições similares. Azevedo (1980, p. 47) esclarece que a elaboração de dois pactos e não de apenas um, foi ditada pelo predomínio da opinião segundo a qual os direitos civis e políticos poderiam ser assegurados de imediato, enquanto os direitos econômicos, sociais e culturais, por dependerem da execução de programas de ação estatal, ficariam condicionados às possibilidades materiais de cada Estado que os implantaria progressivamente "até o máximo de seus recursos disponíveis".

Mas, para Comparato (2003, p. 276), a realização de dois documentos deu-se basicamente por razões políticas. Os ricos Estados ocidentais insistiam no reconhecimento tão somente das liberdades individuais clássicas, protetoras da pessoa humana contra os abusos e as interferências dos órgãos estatais na vida privada. Já os países do bloco comunista e os jovens países africanos preferiam pôr em destaque os direitos sociais e econômicos, que têm por objetivo políticas públicas de favorecimento a grupos ou classes menos favorecidas, deixando na sombra as liberdades individuais.

Así pues, puede afirmarse que la distinción entre derechos civiles y políticos y derechos económicos, sociales y culturales fue el resultado de una decisión política de los Estados, que decidieron identificarlos de uno u otro modo al adscribirlos a uno u otro Pacto Internacional. (CASTILHO, 2003, p. 56)

A elaboração dos pactos foi protelada por uma série de dificuldades de ordem prática e política e, finalmente, em 16 de dezembro de 1966, a Assembleia Geral aprovou, por meio da Resolução n. 2.200A, o texto dos dois Pactos (CARVALHO, 1998, p. 59). Aprovou ainda o Protocolo Facultativo ao Pacto de Direitos Civis e Políticos. Por esse Protocolo criou-se um Comitê de Direitos Humanos, com competência para receber

9 Pacto Internacional sobre Direitos Econômicos, Sociais e Culturais. (Artigo 2 ${ }^{\circ}$ alínea 1). 
e examinar comunicações de particulares vítimas de violações pelo seu Estado, de quaisquer direitos enunciados no Pacto, depois de esgotados os recursos internos. O Estado contra o qual se reclamou terá seis meses para apresentar ao Comitê as explicações ou as declarações necessárias. Evidentemente, somente os Estados que aderirem ao Protocolo Facultativo estão sujeitos à jurisdição do Comitê. Esse foi o grande objeto de discórdia na adoção dos Pactos. Enquanto os dois pactos foram aprovados por unanimidade pela Assembleia Geral, o Protocolo teve dois votos contrários e 38 abstenções, da União Soviética e de seus aliados, bem como de Estados asiáticos, africanos e árabes, temendo ingerência em sua política interna, também de Estados Europeus porque já se julgavam fiscalizados pela Convenção Europeia de Direitos Humanos. (ALVES, 1994, p. 50)10

Para Velasco, a adoção dos Pactos constitui

[...] un cambio cualitativo en el tratamiento de los Derechos $\mathrm{Hu}-$ manos, ya que se trata de instrumentos convencionales que imponen obligaciones jurídicas directamente vinculantes para los Estados-partes. (VELASCO, 1996, p. 231)

Não obstante, os dois documentos terem disposições em comum a começar por seus preâmbulos em que reafirmam os princípios da Carta da ONU, sustentando que o "[...] reconhecimento da dignidade inerente a todos os membros da família humana e de seus direitos iguais e inalienáveis constitui o fundamento da liberdade, da justiça e da paz no mundo [...]", reconhecendo que esses direitos " [...] decorrem da dignidade inerente à pessoa humana [...]" e que "[...] em conformidade com a Declaração Universal dos Direitos do Homem o ideal do ser humano livre, no gozo de suas liberdades civis e políticas e liberto do temor e da miséria, não pode se realizado a menos que se criem condições que permitam a cada um gozar de seus direitos civis e políticos, assim como de seus direitos econô-

\footnotetext{
10 Referindo-se a esta controvérsia, lembra Alves que desde a década de 1940 países como a Austrália e o Uruguai propugnavam pela criação de uma Corte Internacional de Direitos Humanos. No extremo oposto, a União Soviética opunha-se a qualquer tipo de mecanismo de verificação. A inclusão do Comitê dos Direitos Humanos no Projeto do Pacto Internacional de Direitos Civis e Políticos somente foi factível na ausência dos delegados da União Soviética e da Ucrânia na sessão.
} 
micos, sociais e culturais [...]", merece destaque a diferença entre ambos, no tocante às obrigações impostas, como consequência lógica da distinta natureza dos direitos reconhecidos. Destarte, enquanto o Pacto de Direitos Civis e Políticos impõe obrigações automáticas, assumindo o Estado o dever de reconhecer e garantir imediatamente os direitos nele previstos, o Pacto de Direitos Econômicos, Sociais e Culturais define direitos cujo gozo só se garante no horizonte, porque o Estado unicamente assume o compromisso de "[...] adotar medidas tanto por esforço próprio como pela assistência e cooperação internacionais, principalmente nos planos econômico e técnico, até o máximo de seus recursos disponíveis, que visem a assegurar, progressivamente, por todos os meios apropriados, o pleno exercício dos direitos reconhecidos no presente Pacto, incluindo, em particular, a adoção de medidas legislativas”.

\section{Pacto Internacional sobre Direitos Econômicos Sociais e Cul- turais}

Em 3 de janeiro de 1976, entra em vigor o Pacto Internacional sobre Direitos Econômicos, Sociais e Culturais ${ }^{11}$. Destaca Alves (1997, p. 44), que esse Pacto é o primeiro e único instrumento jurídico de abrangência genérica e escopo mundial a conferir obrigatoriedade e proteção aos direitos humanos de "segunda geração" - reconhecidos como fundamentais apenas intuitivamente pelo iluminismo e consagrados como direitos pela Declaração Universal de 1948. E alerta Castillo (2003, p. 57-58), que os direitos econômicos, sociais e culturais são geralmente considerados como direitos de segunda categoria, comparando-se com os direitos civis e políticos, mas,

[...] hay que reconocer que los términos en los que fue redactado y adoptado el Pacto Internacional de Derechos Económicos, Sociales y Culturales, en comparación con el tenor literal del Pacto Interna-

\footnotetext{
${ }^{11}$ Após a Jamaica $\left(35^{\circ}\right.$ Estado) haver depositado seu respectivo instrumento de ratificação, em 3 de dezembro de 1975 - nos termos do artigo 27 do Pacto. O Brasil ratificou em 24 de janeiro de 1992.
} 
cional de Derechos Civiles y Políticos, parecen justificar esas apreciaciones.

Constituído de preâmbulo e 31 artigos, nele estão basicamente discriminados os direitos já previstos nos artigos 22 a 27 da Declaração Universal dos Direitos do Homem: direito ao trabalho, a gozar de condições de trabalho justas e favoráveis, com salário equitativo, direito de fundar sindicatos e a ele filiar-se, direito à previdência social, à assistência e à proteção à família e às crianças; a gozar de uma vida digna para si e sua família; direito ao desfrute do mais alto nível possível de saúde física e mental; direito à educação, direito a participar da vida cultural e de gozar dos benefícios do progresso científico.

Segundo o Comitê de Direitos Humanos, opinião manifestada em vários ordenamentos internos, algumas das disposições desse Pacto podem ser consideradas de aplicação imediata. É o caso do direito a um salário equitativo e à remuneração igual por trabalho igual, do direito à sindicalização, do direito de liberdade dos pais na escolha da escola para a educação dos filhos e do direito à liberdade indispensável para a pesquisa científica.

O Pacto admite que o Estado-Parte possa estabelecer limitações ao gozo desses direitos, mas somente "[...] na medida compatível com a natureza desses direitos e exclusivamente com o objetivo de favorecer o bem-estar geral em uma sociedade democrática". Por outro lado, devem os Estados apresentar relatórios “[...] sobre as medidas que tenham adotado e sobre o progresso realizado com o objetivo de assegurar a observância dos direitos reconhecidos no Pacto". Os relatórios são enviados ao Secretário-Geral da ONU, o qual enviará cópias deles ao Conselho Econômico e Social para exame. Como se verifica, o Pacto Internacional sobre Direitos Econômicos, Sociais e Políticos não possuía, a exemplo do Pacto sobre Direitos Civis e Políticos, um órgão fiscalizador, que somente foi criado pelo Conselho Econômico e Social com o voto contrário dos EUA, em 1987, e denominado Comitê de Direitos Econômicos, Sociais e Culturais. É composto de 18 peritos com a incumbência de examinar os relatórios nacionais em sessão pública. 


\section{Pacto Internacional sobre Direitos Civis e Políticos}

Em 23 de março de 1976, entra em vigor o Pacto Internacional sobre Direitos Civis e Políticos ${ }^{12}$, que se constitui de preâmbulo e 53 artigos. Esse Pacto impõe uma obrigação internacional aos Estados-Partes na concretização dos "direitos de primeira geração" - aqueles que primeiramente foram reconhecidos como direitos humanos pelos filósofos do Iluminismo, bem como na Declaração Americana de 1776 e Francesa de 1789. Além de descrever, aprofundar e ampliar os direitos previstos na Declaração Universal, ele obriga os Estados a "[...] respeitar e a garantir a todos os indivíduos que se achem em seu território e que estejam sujeitos a sua jurisdição os direitos reconhecidos no presente pacto [...]", também permite, em situações excepcionais, suspender o gozo dos direitos nele previstos, "na estrita medida exigida pela situação" e desde que tais medidas "[...] não acarretem discriminação alguma apenas por motivos de raça, cor, sexo, língua, religião ou origem social"13.

Os direitos e as liberdades reconhecidos neste Pacto são: o direito à vida, à proibição de torturas e de penas ou de tratamento cruel, desumano ou degradante; à proibição da escravidão, da servidão e dos trabalhos forçados; o direito à liberdade e à segurança pessoal; o direito a ser tratado com humanidade em caso de privação de liberdade; o direito à liberdade de ir e vir; à proibição de expulsão arbitrária de estrangeiros; o direito a um juízo justo e à presunção de inocência, o princípio da legalidade; o direito ao reconhecimento da personalidade jurídica do ser humano; o direito ao respeito da vida privada e familiar; o direito à liberdade de pensamento, de consciência e de religião; o direito à liberdade de expressão; o direito de reunião pacífica; o direito à liberdade de associação; o direito a

\footnotetext{
12 Três meses após a Tcheco-Eslováquia ( $35^{\circ}$ Estado) haver depositado seu respectivo instrumento de ratificação em 23 de dezembro de 1975 - nos termos do artigo 49 do Pacto. O Brasil ratificou em 24 de janeiro de 1992.

13 Gozam de proteção absoluta, isto é, não podem ser suspensos mesmo em situações excepcionais: o direito à vida; os direitos derivados da proibição de tortura, penas cruéis, degradantes ou desumanas; a proibição da escravidão; a proibição de prisão civil; o princípio da legalidade; o reconhecimento da personalidade jurídica do homem; o direito a liberdade de pensamento, de consciência e de religião.
} 
contrair matrimônio e a constituir família; o direito de votar, de ser eleito e de ter acesso às funções públicas; o direito à igualdade ante a lei.

Como se observa, alguns direitos reconhecidos pela Declaração Universal não receberam guarida nos Pactos, como o direito de asilo em caso de perseguição, o direito a uma nacionalidade e o direito à propriedade (ALVES, 1994, p. 50). Por outro lado, surgem novos direitos e garantias não previstos na Declaração, como o direito à autodeterminação, à proibição de prisão civil; à proibição de qualquer propaganda em favor da guerra, da apologia ao ódio racial, nacional ou religioso; o direito das crianças à proteção e a uma nacionalidade; e o direito das minorias étnicas a professar e a praticar sua própria religião, língua e costumes.

Importante destacar que os Estados estão obrigados a tomar as medidas legislativas necessárias para dar efeito aos direitos estabelecidos, bem como um justo remédio às violações sofridas.

\section{A Situação Latino-Americana}

Foi de Simon Bolívar o sonho de unificar a América Latina em uma República que consagrasse as ex-colônias espanholas. Comungando o pensamento liberal, Bolívar expõe as ideias que dão as diretrizes para nortear o Congresso do Panamá de 1826. Bolívar imaginava uma estrutura institucional que integrasse as antigas colônias espanholas, evidentemente excluindo o Brasil e Estados Unidos da América (SANTOS, 1998, p. 19-27) ${ }^{14}$. A instalação solene do Congresso do Panamá ocorreu em 22 de junho de 1826 e entre suas principais conquistas estava o Tratado de União, Liga e Confederação Perpétua, pactuado entre os participantes. Encerrado em 15 de julho daquele ano, o Tratado somente foi ratificado pelo governo colombiano, não tendo jamais entrado em vigor.

\footnotetext{
14 Bolívar não desejava a participação do Brasil, pois idealizava uma Confederação que reunisse tão somente antigas colônias espanholas na América e também porque vislumbrava no Império brasileiro pretensões imperialistas por sobre seus vizinhos. Também não desejava a participação dos Estados Unidos da América por não ser excolônia espanhola e por desconfiar que a Doutrina de Monroe configurasse uma ameaça de intervenção.
} 
Apesar do fracasso da tentativa, esse Congresso é o antecedente histórico da Organização dos Estados Americanos.

Longo foi o caminho até Bogotá, quando a $9^{\circ}$ Conferência Internacional Interamericana aprovou, finalmente, em 30 de abril de 1948, o Estatuto definitivo da Organização dos Estados Americanos - OEA (ACCIOLY; SILVA, 1996, p. 208) ${ }^{15}$, que em seu considerando declara estarem

15 Após o fracasso do Congresso do Panamá, não faltaram esforços para unir os Estados Americanos; o México tentou reuni-los em 1831, 1838 e 1840, sem resultado. O Peru promoveu dois congressos, 1847 e 1864. Em ambos foram assinados várias convenções, jamais ratificadas. Por iniciativa do secretário de Estado norte-americano, James Blaine, de 1889 a 1890, ocorre em Washington, a $1^{\circ}$ Conferência Internacional dos Países Americanos, ocasião em que foi formada a União Internacional das Repúblicas Americanas. Na mesma oportunidade criou-se o Escritório Comercial das Repúblicas Americanas, cuja finalidade era compilar, coordenar e publicar dados e informações referentes à produção e comércio dos Estados americanos. Esse Escritório estava vinculado diretamente ao Departamento de Estado dos Estados Unidos. Em 1902, na $2^{\circ}$ Conferência Internacional das Repúblicas Americanas, na cidade do México, o Escritório tomou o nome de Escritório Internacional das Repúblicas Americanas, passando a ser dirigido por um Conselho constituído pelos Embaixadores dos Estados Americanos. É na $3^{\circ}$ Conferência Internacional das Repúblicas Americanas, realizada no Rio de Janeiro em 1906 que o Escritório passa a denominar-se Comissão Permanente das Conferências Internacionais Americanas cuja função passa a ser de preparar as conferências. Em 1910, na IV Conferência, levada a efeito em Buenos Aires, a Comissão passa a denominar-se União Pan-Americana. Na Conferência de Santiago do Chile, em 1923, ficou estabelecido que a representação dos Estados-Membros junto à União Pan-Americana seria constituída de representantes designados pelos respectivos Estados para esse fim específico e não pelos seus embaixadores, como vinha ocorrendo. Ficou acordado também que a presidência da organização seria pela eleição de um de seus membros e não obrigatoriamente pelo secretário de Estado norte-americano. Em 1945, na Conferência do México, a União Pan-Americana sofre reformulação em seus objetivos, passando a constituir-se num "acordo regional para tratar de assuntos referentes à paz e à segurança". Esses novos objetivos vão se materializar com a assinatura do Tratado Interamericano de Assistência Recíproca (TIAR) em setembro de 1947. Finalmente, já estruturada e com seus objetivos definidos, no dia 30 de abril de 1948, em Bogotá, na $9^{\circ}$ Conferência Internacional Interamericana, a União Pan-Americana passa a denominar-se Organização dos Estados Americanos (OEA), ocasião em que tem sua Carta aprovada. Ela foi reformada em 1967 pela $3^{\text {a }}$ Conferência Interamericana Extraordinária, realizada em Buenos Aires e em 1985, mediante o "Protocolo de Cartagena das Índias". Mais tarde, em 1992, o Protocolo de Washington introduz modificações adicionais, o mesmo ocorrendo no Protocolo de Manágua, em 1993. A OEA conta atualmente com 35 Estados. Como ensina Accioly, a OEA não surgiu de improviso, nem no anseio de pôr fim a uma 
os Estados Americanos “[...] convencidos de que a missão histórica da América é oferecer ao homem uma terra de liberdade e um ambiente favorável ao desenvolvimento de sua personalidade e à realização de suas justas aspirações [...]” e certos de que devem consolidar no Continente, “[...] dentro de um quadro de instituições democráticas, um regime de liberdade individual e de justiça social, fundado no respeito aos direitos essenciais do Homem”. Assim, em seus princípios “[...] proclamam os direitos fundamentais da pessoa humana, sem fazer distinção de raça, nacionalidade, credo ou sexo".

A mesma conferência que aprovou a Carta da OEA proclamou também, em 2 de maio de 1948, a Declaração Americana dos Direitos e dos Deveres do Homem, portanto, sete meses antes que a Assembleia Geral das Nações Unidas proclamasse, em 10 de dezembro, a Declaração Universal dos Direitos do Homem. Dessa forma, assim como a OEA é a mais antiga organização de cunho genérico existente, a Declaração Americana dos Direitos e Deveres do Homem é o primeiro documento internacional relativo à proteção dos direitos humanos.

$\mathrm{Na}$ Declaração, os Estados Americanos reconhecem que suas instituições, jurídicas e políticas "[...] têm como finalidade principal a proteção dos direitos essenciais do homem e a criação de circunstâncias que lhe permitam progredir espiritual e materialmente e alcançar a felicidade [...]", reconhecem também que "[...] os direitos essenciais do homem não derivam do fato de ser ele cidadão de determinado Estado, mas sim do fato dos direitos terem como base os atributos da pessoa humana [...]" e que a proteção dos direitos do homem deve ser a orientação principal do direito americano em evolução ${ }^{16}$.

época de guerras; foi o efeito de longa e pacífica evolução que se vinha consolidando desde mais de um século, embora, como verdadeira associação de Estados, só começou a aparecer e de forma rudimentar na $1^{\circ}$ Conferência Internacional dos Países Americanos, realizada em Washington, de 1889 a 1890.

16 Tanto a Declaração Americana, como as disposições da Carta da OEA, referente aos Direitos Humanos, possuem importantes antecedentes, adotados anteriormente em reuniões e em conferências Interamericanas. Os primeiros antecedentes constam em algumas resoluções aprovadas na $8^{\circ}$ Conferência Internacional Americana, em Lima, 1938, como: a Resolução sobre "Livre Associação e Liberdade de Expressão dos 
Assim reconhecem, "sem distinção de raça, língua, crença, ou qualquer outra", os seguintes direitos civis, políticos, econômicos, sociais e culturais: direito à vida, à liberdade e à segurança pessoal; à igualdade perante a lei; à liberdade religiosa; à liberdade de opinião e de expressão; à defesa de sua honra e reputação, bem como de sua família; direito ao matrimônio e a constituir família; proteção à gestação e à infância; direito de ir e vir; direito à inviolabilidade de domicílio e de correspondência; direito que sua saúde seja resguardada por medidas sanitárias e sociais; direito à educação; à cultura; às artes; aos benefícios do progresso; direito ao trabalho em condições dignas; à oportunidade de seu melhoramento espiritual, cultural e físico; direito à previdência social; à personalidade jurídica; ao acesso à justiça; a uma nacionalidade; direito à participação política; de reuniu-se pacificamente; direito de livre associação; direito à propriedade privada; direito de peticionar junto a autoridades; a ter garantias contra a prisão arbitrária; à proibição de prisão civil; direito a um tratamento humano quando em detenção; à presunção de inocência; direito a um tribunal imparcial; à proibição de penas cruéis, infamantes ou inusitadas e direito a asilo.

Se a Declaração Universal dos Direitos do Homem proclamada pela Assembleia Geral das Nações Unidas sofre a crítica de não prever contrapartida aos direitos do homem, isto é, não haver referência a deveres, “[...] principalmente quando se sabe que, hoje, o problema dos deveres não está solucionado em todos os campos que interessam a sociedade contemporânea [...]" (LEAL, 1997, p. 88), o mesmo não pode ocorrer com a Declaração Americana, pois essa Declaração destacou em dez artigos os deveres do cidadão: dever de conviver respeitosamente em sociedade; dever para com os filhos e pais; dever de educar-se; de participar politicamente; de obedecer as leis; de prestar serviços civis e militares ao

Operários", a "Declaração de Lima em favor dos Direitos da Mulher", A Resolução XXXVI em que as Repúblicas Americanas declaram que toda perseguição, por motivos racial ou religioso, contraria os regimes políticos e jurídicos da América e, especialmente, a "Declaração em Defesa dos Direitos Humanos", na qual se assinala a preocupação dos Estados Americanos com o conflito armado que se aproximava, afirmando que, quando se recorrer à guerra "[...] em qualquer parte do mundo, se respeitem os direitos humanos não comprometidos na luta, os sentimentos humanitários e o patrimônio espiritual e material da civilização". (Ver: <www. oea.org>). 
Estado; de pagar impostos; de trabalhar; de abster-se de atividades políticas em país estrangeiro.

Contudo, a exemplo da Declaração Universal da ONU, a Declaração Americana, do ponto de vista formal, não é um instrumento juridicamente vinculante.

Em 1959, em Santiago do Chile, a $5^{\circ}$ Reunião de Consulta dos Ministros das Relações Exteriores da Organização dos Estados Americanos (OEA) aprovou importantes resoluções sobre o desenvolvimento e o fortalecimento do sistema interamericano de direitos humanos. A Declaração de Santiago proclama que "[...] a harmonia entre as Repúblicas Americanas só pode existir enquanto o respeito aos direitos humanos e às liberdades fundamentais e o exercício da democracia representativa forem realidade, no âmbito interno de cada uma delas [...]" e declara que "[...] os governos dos Estados Americanos devem manter um regime de liberdade individual e de justiça social fundado no respeito dos direitos fundamentais da pessoa humana". O mais importante documento dessa reunião de consulta foi a Resolução referente aos direitos humanos. Nela declarou-se que o progresso alcançado em matéria de direitos humanos, 11 anos depois de proclamada a Declaração Americana, havia criado um clima no Hemisfério para se celebrar uma Convenção e considerou-se " [...] indispensável que esses direitos sejam protegidos por um regime jurídico, a fim de que o homem não se veja obrigado ao recurso supremo da rebelião contra a tirania e a opressão" (OEA).

Dessa forma, foi criada a Comissão Interamericana de Direitos Humanos (CIDH), cuja função, inicialmente, era apenas a de promover - e não de proteger - os direitos humanos, funcionando como órgão autônomo do sistema da OEA. Aos poucos, contudo, suas funções institucionais foram sendo fortalecidas.

No ano de 1965, a II Conferência Interamericana Extraordinária realizada no Rio de Janeiro, emendou o Estatuto da CIDH, ampliando suas competências, transformando-se em instrumento de controle, com autorização para receber e examinar petições e comunicações individuais, que contenham denúncias de violações de direitos proclamados na Declaração Americana, bem como competência para dirigir-se aos Estados Ameri- 
canos, a fim de obter informações e formular recomendações, além de determinar que a Comissão apresente, anualmente, um relatório, para a Conferência Interamericana, ou promova uma Reunião de Consulta dos Ministros das Relações Exteriores, com exposição sobre o progresso alcançado na execução dos objetivos definidos na Declaração Americana. Entretanto, por ter a Comissão sido criada em reunião de Ministros, sua base legal foi posta em dúvida. Alguns Estados começaram a questionar sua competência de exigir informações e fazer recomendações.

Então, em fevereiro de 1967, pelo Protocolo de Buenos Aires, foi emendada a Carta da Organização dos Estados Americanos, modificando a condição jurídica da Comissão Interamericana de Direitos Humanos - que passa a incorporar a própria carta - fortalecendo seu caráter normativo. Foi lhe conferido status de órgão principal da Organização e a função de "[...] promover o respeito e a defesa dos direitos humanos e servir como órgão consultivo da Organização em tal matéria". A Carta reformada previa também que "uma Convenção Interamericana sobre Direitos Humanos" deveria determinar "[...] a estrutura, a competência e as normas de funcionamento da referida Comissão, bem como as dos outros órgãos encarregados de tal matéria". Até lá, a $\mathrm{CIDH}$, na forma existente, deveria fazer valer sua competência e velar na defesa dos direitos humanos.

Para Castillo (2003, p. 141-142):

[...] de esta forma, el Protocolo de Buenos Aires, atribuyó a la Comisión la legitimidad "constitucional" de la que carecía los procedimientos existentes de actuación de aquélla e, implícitamente, reconoció el valor jurídico de la Declaración Americana de los Derechos y Deberes del Hombre, puesto que ésta era el instrumento que la Comisión debía aplicar en virtud de su Estatuto.

A Convenção Americana sobre Direitos Humanos, a que se referia o Protocolo de Buenos Aires, e que deveria dar estrutura e competência às normas de funcionamento da $\mathrm{CIDH}$, teve seu projeto elaborado pelo Conselho Interamericano de Jurisconsultos e submetido à OEA, a fim de serem ouvidos os comentários dos Estados e da Comissão, que apresenta um novo projeto. Para analisar as diferentes propostas, foi convocada a 
Conferência Especializada Interamericana sobre Direitos Humanos, que se reuniu em São José, na Costa Rica, em 7 de novembro de 1969. No dia 21 , foi aprovado o seu texto e aberto para assinaturas no dia seguinte -22 de novembro de 1969. Somente entrou em vigor quando os 11 Estados já haviam depositado na Secretaria Geral da OEA seus respectivos instrumentos de ratificação, isso ocorreu em 18 de julho de 1978 (o depósito do instrumento de ratificação brasileiro ocorreu em 25 de setembro de 1992).

\section{Convenção Americana sobre Direitos Humanos}

Ao aprovar a Convenção Americana sobre Direitos Humanos, ou Pacto de São José, os Estados Americanos demonstraram haver “[...] superado a fase de elaboração de princípios teóricos e das meras declarações de intenções.” (ACCIOLY; SILVA, 1996, p. 372)

$\mathrm{Na}$ Convenção, em seu preâmbulo, os Estados reafirmam seu propósito de consolidar um regime fundado nos direitos humanos e reconhecem que os direitos essenciais do homem derivam do fato de ter como fundamento os atributos da pessoa humana, o que justifica uma proteção internacional. Embora os Estados possam, em raras situações, como a guerra, suspender algumas garantias ${ }^{17}$, expressamente obrigam-se a respeitar os direitos e as liberdades previstas na Convenção, sem qualquer discriminação, seja por motivo de raça, cor, sexo, idioma, religião, opiniões políticas ou de qualquer outra natureza, origem nacional ou social, posição econômica, nascimento ou qualquer outra condição social.

Os direitos e garantias referidos pela convenção são: direito à vida; direito à integridade pessoal; à proibição da escravidão e da servidão; direito à liberdade pessoal; direito às garantias judiciais; à garantia do princípio da legalidade e da irretroatividade; direito à indenização; direito à proteção da honra e da dignidade; à liberdade de consciência e de religião; à liberdade de pensamento e de expressão; direito à resposta; direito

\footnotetext{
17 Não podem ser suspensos: o direito à vida, ao reconhecimento da personalidade jurídica, à integridade pessoal; a proibição da escravidão e servidão; o princípio da legalidade e da retroatividade; a liberdade de consciência e de religião; a proteção à família, o direito ao nome; a proteção à criança; o direito à nacionalidade; e os direitos políticos.
} 
à reunião; à associação; a constituir família; direito ao nome; a medidas de proteção à criança; à nacionalidade; à propriedade privada; direito à circulação e a residências; direito a participar da vida política; à igualdade perante a lei e direito à proteção judicial dos direitos fundamentais.

Quanto aos direitos que decorrem das normas econômicas, sociais e sobre educação, ciência e cultura, constantes da Carta da OEA (do artigo 30 ao artigo 52), os Estados comprometem-se a adotar todas as providências necessárias, por via legislativa ou por outros meios apropriados, a fim de conseguir progressivamente, sua plena efetivação.

Assim como a Declaração Americana dos Direitos e Deveres do Homem, a Convenção Americana sobre Direitos Humanos também prevê deveres. Expressa que, "[...] toda pessoa tem deveres para com a família, a comunidade e a humanidade". E também, a exemplo da Declaração, estabelece os limites dos direitos: "Os direitos de cada pessoa são limitados pelos direitos dos demais, pela segurança de todos e pelas justas exigências do bem comum, numa sociedade democrática" (artigo 32).

\section{A Comissão Interamericana de Direitos Humanos}

Após a enumeração dos direitos e dos deveres, em sua segunda parte, a Convenção estabelece os meios de proteção. Conforme previsto no Protocolo de Buenos Aires, passa a determinar, a organização, a estrutura, as funções, a competência e os procedimentos da Comissão Interamericana de Direitos Humanos (CIDH). A Comissão, com sede em Washington, é composta por sete membros, eleitos pela Assembleia Geral da OEA, dentre os indicados pelos Estados-Membros ${ }^{18}$, recebeu como função principal "[...] promover a observância e a defesa dos direitos humanos", sem prejuízo de suas competências anteriores.

\footnotetext{
18 Cada Estado-Parte pode indicar até três candidatos de sua nacionalidade, pessoas de alta autoridade moral e de reconhecido saber em matéria de direitos humanos. Os membros que comporão a Comissão Interamericana de Direitos Humanos são eleitos, a título pessoal, pela Assembleia Geral para o período de quatro anos, podendo ser reeleitos uma única vez. Não pode fazer parte da Comissão mais de um nacional de um mesmo Estado.
} 
Assim, no exercício de sua função principal, há as seguintes atribuições: (a) estimular a consciência dos direitos humanos nos povos da América; para tanto promove conferências e reuniões para difundir e debater temas específicos (direito dos indígenas, das mulheres, das crianças), também promove estudos e publicações; (b) fazer recomendações aos Estados-Membros para a adoção de medidas - no âmbito de suas leis internas e seus preceitos constitucionais - que contribuam com a promoção e a efetivação dos direitos humanos, bem como requer que adotem "medidas cautelares" para evitar danos graves e irreparáveis aos direitos humanos em casos urgentes; (c) observar a situação geral dos direitos humanos nos Estados-Membros - inclusive com visitas in loco, se necessário - publicando estudos e relatórios que julgar conveniente para o desempenho de sua função principal; (d) solicitar aos Estados-Membros informações sobre medidas adotadas em matéria de direitos humanos; (e) atender às consultas formuladas pelos Estados-Partes e prestar-lhes assessoramento sobre questões relacionadas aos direitos humanos; (f) receber, analisar e investigar petições individuais que alegam violações aos direitos e às liberdades previstos na Convenção, submetendo os casos comprovados à jurisdição da Corte Interamericana de Direitos Humanos, que atua na defesa dos direitos; (g) apresentar um relatório anual à Assembleia Geral.

Pela Convenção, os Estados-Partes obrigatoriamente reconhecem a competência da Comissão para a consideração de queixas individuais; já as comunicações estatais, somente serão admitidas e examinadas se apresentadas por um Estado que haja reconhecido expressamente a competência da Comissão. (GARCIA, 2005, p. 85; CARBONELL, 2003, p. 117)

$\mathrm{O}$ artigo 23 do Regulamento da $\mathrm{CIDH}$ estabelece que denúncias ou queixas podem ser oferecidas por qualquer pessoa, individualmente ou em grupo, ou qualquer entidade não governamental.

\section{A Corte Interamericana de Direitos Humanos}

A ideia de se criar um tribunal para proteger os direitos humanos na América remonta à $9^{\circ}$ Conferência Internacional Americana realizada em Bogotá, 1948 - quando a União Pan-Americana passa a denominar-se Or- 
ganização dos Estados Americanos (OEA). Na oportunidade, aprovou-se também a Resolução XXXI, denominada "Corte Interamericana para proteger os direitos do homem", na qual se considerou que a proteção desses direitos "[...] deve ser garantida por um órgão jurídico, visto que não há direito devidamente garantido sem o amparo de um tribunal competente".

Tal pretensão foi alcançada em São José da Costa Rica quando se aprovou a criação da Corte Interamericana de Direitos Humanos ${ }^{19}$ com competência consultiva e contenciosa para conhecer sobre qualquer caso relativo à interpretação e à aplicação das disposições da Convenção Americana sobre Direitos Humanos. É composta por sete juizes nacionais dos Estados-Membros, eleitos por votação secreta pela maioria absoluta da Assembleia Geral da OEA, dentre os juristas da mais alta autoridade e de reconhecida competência em matéria de direitos humanos indicados pelos Estados.

A competência consultiva é ampla, prevê que qualquer Estado-Membro da OEA, parte ou não da Convenção, poderá consultar a Corte sobre a interpretação da Convenção Americana ou de outros Tratados concernentes à proteção dos direitos humanos nos Estados Americanos. Também, por solicitação de qualquer Estado-Membro da OEA, a Corte emitirá parecer sobre a compatibilidade de qualquer de suas leis internas e os instrumentos jurídicos internacionais.

19 Os Estatutos da Corte Interamericana de Direitos Humanos foram aprovados na Assembleia Geral da OEA em La Paz, em 1979 sendo definida em seu artigo $1^{\circ}$ como "[...] uma instituição judiciária autônoma, cujo objetivo é a aplicação e a interpretação da Convenção Americana sobre Direitos Humanos". A corte instalou-se oficialmente em sua sede em São José, Costa Rica, em 3 setembro de 1979. Seu primeiro Regulamento, aprovado em julho de 1980, foi inspirado no Regulamento da Corte Europeia de Direitos Humanos que, por sua vez, havia adotado o modelo de Regulamento da Corte Internacional de Justiça. A fim de agilizar seus procedimentos, a Corte alterou seu Regulamento em 1991, mais tarde, em 16 de setembro de 1996, a Corte adotou novo Regulamento, que entrou em vigor em $1^{\circ}$ de janeiro do ano seguinte. Como principal modificação foi concedido aos representantes das vítimas ou de seus familiares o direito de apresentar seus próprios argumentos e provas na etapa de reparações. Por fim, em 24 de novembro de 2000, nova modificação no Regulamento da Corte. Essa reforma entrou em vigor em $1^{\circ}$ de janeiro de 2001 e introduziu uma série de medidas destinadas a permitir às supostas vítimas, aos seus familiares ou aos seus representantes a participação direta em todas as etapas do processo. 
Quanto ao contencioso, a Corte tem competência limitada aos Estados-Partes que tenham reconhecido ou que reconheçam sua competência (o Brasil reconheceu a competência da Corte em 10 de dezembro de 1998). Nesse particular, lembra Cançado Trindade (2003, p. 222) e complementa Carbonell (2003, p. 109-110), que:

[...] os Tribunais Internacionais de Direitos Humanos existentes as Cortes Européia e Interamericana de Direitos Humanos - não substituem os Tribunais internos, e tampouco operam como tribunais de recursos ou cassação de decisões dos Tribunais internos. Não obstante, os atos internos dos Estados podem vir a ser objeto de exame por parte dos órgãos de supervisão internacionais.

O processo inicia com a distribuição da demanda junto à Secretaria da Corte, em qualquer idioma oficial da corte (espanhol, francês, inglês, português - somente os Estados-Partes e a Comissão têm direito de submeter caso à decisão da corte - artigo 61). A produção de provas e audiências ocorre da mesma forma que na CIDH, com a diferença de que na Corte as partes do processo passam a ser, de um lado o Estado-Denunciado e de outro a Comissão. O processo tem duas fases, uma escrita outra oral. Na fase oral, os agentes do Estado, seus advogados ou conselheiros apresentam o caso ao Presidente da Corte, eles podem também apresentar testemunhas e perícias. Todo procedimento é público, exceto se a Corte dispor o contrário. A Comissão Interamericana de Direitos Humanos deve se fazer presente e será vista como parte ante a Corte em todos os casos relativos à função jurisdicional dela.

Quando a Corte decidir que houve violação a um direito ou à liberdade, protegidos pela Convenção, ela determinará que se garanta ao prejudicado o gozo de seu direito ou liberdade violados. Poderá também, determinar que sejam reparadas as consequências da medida, mediante o pagamento de justa indenização à parte lesada. Como ensina Belli (1998, p. 166), a Corte não é um tribunal penal e não substitui as ações penais relativas às violações cometidas nos Estados, ela apenas julga se o Estado é ou não responsável por violação à Convenção Americana sobre Direitos Humanos (GORCZEVSKI, 2009, p. 177). Sendo considerado responsá- 
vel, o Estado assume a obrigação de fazer cessar a violação e de indenizar a vítima.

As sentenças devem ser fundamentadas, admitindo-se a juntada de voto vencido. São definitivas e inapeláveis, contudo, havendo divergência quanto ao seu alcance, podem as partes pedir, no prazo de 90 dias, interpretação (análogo a embargos declaratórios). A sentença será lida em audiência pública depois de notificadas as partes, e será dado conhecimento a todos os Estado-Parte da Convenção. Havendo indenização compensatória, a parte interessada poderá executar a sentença no seu respectivo país, pelo processo vigente para a execução de sentenças contra o Estado.

No caso do um Estado não dar cumprimento às decisões da Corte, ela, "[...] de maneira especial e com as recomendações pertinentes [...]", em seu relatório anual, indicará o caso e se submeterá à consideração da Assembleia Geral da OEA.

\section{Conclusões}

A presente pesquisa teve como objetivo demarcar (de forma histórico-cronológica) os principais documentos internacionais na órbita dos direitos humanos, especialmente no que tange a uma perspectiva global do tema, haja vista a preocupação não somente com aspectos de natureza interna, mas, principalmente, de cunho de direito internacional. O latente enfoque justifica-se a partir dos pontos de vista demonstrados, pois aludiu-se como as influências políticas, religiosas e internas de cada nação eram capazes de conduzir o tratamento internacional dos direitos humanos a rumos não pretendidos ou tão somente buscando adequar-se a interesses próprios.

Restou clara a modificação de rumos de cunho internacional no período após a Segunda Guerra Mundial, um dos exemplos disso foi citado na própria discussão sobre o papel do indivíduo nas relações internacionais, chegando, inclusive, nas fundamentações modernas, a ser afirmado como um sujeito de direito. Portanto, esse novo pensamento na visão jurisdicional internacional, somada à gama de tratados, pactos e convenções advindas nesse novo período, traz o substrato ético-jurídico renovado aos 
direitos humanos, já que a orientação sob o viés da dignidade humana faz-se flagrante nos rumos tomados na proteção internacional da humanidade e seus direitos.

As possibilidades inicialmente reservadas somente aos Estados ou a determinados organismos foram sendo ampliadas a fim de reservar não apenas um maior número de componentes do plano internacional, mas também efetivar a coalizão entre o pensamento jusfilosófico da modernidade e os compromissos internacionais assumidos. Pautando, desse modo, marcos diferenciados, seja na esfera europeia, africana ou latino-americana, de proteção real dos direitos humanos.

Por tudo isso, compreende-se como de destaque o papel do plano internacional no direito pós-moderno, para concretizar a defesa dos direitos humanos, sendo que, dessa forma, funcionaliza-se um sistema singular, que, ao mesmo tempo, conjuga forças de cunho jurisdicional, político e moral, na busca de um objetivo comum, a proteção dos seres humanos em toda a sua essência e valia axiológica.

\section{Referências}

ACCIOLY, Hildebrando; SILVA, Geraldo Eulálio do Nascimento e. Manual de direito internacional público. 12. ed. São Paulo: Saraiva, 1996.

ALVES, J. A. Lindgren. Os direitos humanos como tema global. São Paulo: Perspectiva; Brasília: Fundação Alexandre de Gusmão, 1994.

. A arquitetura internacional dos direitos humanos. São Paulo:

FTD, 1997.

ANDRADE, Agenor Pereira de. Manual de direito internacional

público. 5. ed. São Paulo: Saraiva, 1990.

AZEVEDO, Ivo Sefton. Direito internacional público. Porto Alegre:

Livraria do Advogado, 1980. 
BELLI, Benoni. O sistema interamericano de proteção aos direitos humanos. In: SILVA. Reinaldo Pereira. (Org.). Direitos humanos como educação para a justiça. São Paulo: LTr, 1998.

BOBBIO, Norberto. A era dos direitos. Rio de Janeiro: Campus, 1992. BODIN, Jean. Les six livres de la repúblique. Paris: Jacques du Puis, 1576.

CALLO, Jorge, Iván Hübner. Panorama de los derechos humanos. Buenos Aires: Editora da UBA, 1977.

CANÇADO TRINDADE, Antonio Augusto. Apresnetação In: PIOVESAN, Flávia. Direitos humanos e o direito constitucional internacional. 4. ed. São Paulo: Max Limonad, 2000.

. Tratado de direito internacional dos direitos humanos. 2. ed., v. I. Porto Alegre: Fabris, 2003.

. A personalidade e capacidade jurídicas do indivíduo como sujeito de direito internacional. In: ANNONI, Danielle (Org.). Os novos conceitos do novo direito internacional: cidadania, democracia e direitos humanos. Rio de Janeiro: América Jurídica, 2002.

CARBONELL, José Carlos Remotti. La corte interamericana de derechos humanos: estructura, funcionamiento y jurisprudencia. Barcelona: Instituto Europeo de Derecho, 2003.

CARVALHO, Júlio Marino de. Os direitos humanos no tempo e no espaço. Brasília: Brasília Jurídica, 1998.

CASTILLO, Mileya. Derecho internacional de los derechos humanos. Valencia: Tirant lo blanch, 2003.

COMPARATO, Fábio Konder. A Afirmação Histórica dos Direitos Humanos. 3. ed. São Paulo: Saraiva, 2003.

GARCIA, Emerson. Proteção internacional dos direitos humanos: breves reflexões sobre os sistemas convencional e não-convencional. Rio de Janeiro: Lumen Juris, 2005.

GORCZEVSKI, Clovis. Direitos humanos, educação e cidadania: conhecer, educar, praticar. Santa Cruz do Sul: Edunisc, 2009. 
LEAL, Rogério Gesta. Direitos humanos no Brasil: desafios à democracia. Porto Alegre: Livraria do Advogado; Santa Cruz do Sul: Edunisc, 1997.

OLIVEIRA. Almir de. Curso de direitos humanos. Rio de Janeiro: Forense, 2000.

PIOVESAN, Flávia. Direitos humanos e globalização. In: SUNDFLD, Carlos Ari; VIEIRA, Oscar Vilhena (Coord.). Direito global. São Paulo: Max Limonad, 1998.

. Direitos humanos e o direito constitucional internacional. 4. ed. São Paulo: Max Limonad, 2000.

REZEK, José Francisco. Curso elementar de direito internacional público. São Paulo: Saraiva, 1995.

. Direito Internacional Público. 10. ed. São Paulo: Saraiva, 2005.

SANTOS, Ricardo Soares Stersi dos. Mercosul e arbitragem internacional. Belo Horizonte: Del Rey, 1998.

SARLET, Ingo Wolfgang. Dignidade da pessoa humana e direitos fundamentais na Constituição Federal de 1988. 5. ed. Porto Alegre: Livraria do Advogado, 2008.

SILVA. Reinaldo Pereira e. (Org.). Direitos humanos como educação para a justiça. São Paulo: LTr, 1998.

SOROETA LICERAS, Juan. La protección de la persona humana en el derecho internacional. In: FERNÁNDEZ DE CASADEVANTE ROMANI, Carlos (Coord.). Derecho internacional de los derechos humanos. Madrid: Dilex, 2000.

VELASCO, Manuel Diez de. Las organizaciones internacionales. Madrid: Techos, 1996.

VERDROSS, Alfred. Derecho internacional público. Madrid: Aguilar, 1961. 